\author{
S.M. Davoodi* ${ }^{*}$ N.A. Abdul Rahman \\ School of Mathematical Sciences, Universiti Sains Malaysia, Penang, Malaysia \\ (E-mail:smd1376@gmail.com, aswad.rahman@usm.my)
}

\title{
Solving fully fuzzy linear programming problems by controlling the variation range of variables
}

\begin{abstract}
This paper deals with a fully fuzzy linear programming problem (FFLP) in which the coefficients of decision variables, the right-hand coefficients and variables are characterized by fuzzy numbers. A method of obtaining optimal fuzzy solutions is proposed by controlling the left and right sides of the fuzzy variables according to the fuzzy parameters. By using fuzzy controlled solutions, we avoid unexpected answers. Finally, two numerical examples are solved to demonstrate how the proposed model can provide a better optimal solution than that of other methods using several ranking functions.
\end{abstract}

Keywords: fully fuzzy linear programming, fuzzy linear programming, fuzzy number, ranking function.

\section{Introduction}

The general idea about fuzzy set theory was introduced by Zadeh [1]. Bellman and Zadeh [2] postulated the very idea of decision making in fuzzy environment. The aforementioned concept has been utilized by Tanaka et al. [3] as a solution for mathematical programming problems. Fuzzy linear programming was first generated and suggested by Zimmerman [4] . Using the parametric programming method, Chanas [5] suggested the contingency of the identification of a complete fuzzy decision in fuzzy linear programming. Programming models with crisp or fuzzy constraints as well as crisp or fuzzy goals can be solved using interactive system proposed by Werners [6].

Using a technique introduced by Fang et al. [7], linear programming problems with fuzzy coefficients in constraints could be solved. In an attempt to find solution for fully fuzzified linear programming problems with fuzzy numbers in place of all the parameters and variables, Buckley and Feuring [8] proposed substitution of the objective function for multiobjective fuzzy linear programming problem. Maleki et al. [9] solved linear programming problems by comparing fuzzy numbers as decision parameters.

The ranking function used and suggested by Maleki [10] is a technique in solving linear programming that has vague and uncertain constraints. By transforming fuzzy linear programming problems into multiobjective linear programming problems, Nehi et al. [11] proposed and defined the concept of optimality for linear programming problems. Ganesan and Veeramani [12] proposed and advocated an approach in which fuzzy linear programming cannot be converted into crisp linear programming in solving a fuzzy linear programming problem using symmetric trapezoidal fuzzy numbers. Hashemi et al. [13] suggested a two-phase method in which fuzzy numbers replace decision parameters and the variables determine the optimal solutions of FFLP problems. Rommelfanger [14] also introduced a new approach in solving stochastic linear programming problems with fuzzy parameters.

Allahviranloo [15] suggested a new method in solving FFLP problems using ranking function. Nasseri [16] proposed a method for solving fuzzy linear programming problems using a classical linear programming model. Lotfi et al. [17] discussed FFLP problems by identifying all parameters and variables as triangular fuzzy numbers. Ebrahimnejad and Nasseri [18] attempted to solve fuzzy linear programming problem with fuzzy parameters by applying the complementary slackness theorem without necessitating the use of the simplex tableau. Kumar et al. [19] proposed a new method in finding the fuzzy optimal solution of FFLP problems with inequality constraints.

In this paper a new method is proposed to find the fuzzy optimal solutions of an FFLP problem with equality and inequality constraints, as well as with triangular and trapezoidal fuzzy numbers, by solving one linear programming problem only. Moreover, by controlling the left and the right sides of the fuzzy variables, this model prevents the generation of broad fuzzy solutions that do not conform to other fuzzy parameters.

\footnotetext{
${ }^{*}$ Corresponding author.

E-mail: smd1376@gmail.comr
} 
One of the problems exhibited by a number of models for FFLP problems is their incapability to simultaneously solve equality and inequality constraints. Buckley and Feuring [8], Hosseinzadeh et al. [17], and Kumar et al. [19] proposed three different models in solving FFLP problems. The model, proposed by Buckley and Feuring, can only be used to solve FFLP problems with inequality constraints, whereas the models proposed by Hosseinzadeh et al. and Kumar et al. can only be used to solve FFLP problems with equality constraints. Another problem is the inability of some models to control the left and the right sides of fuzzy numbers, thus generating broad answers and causing difficulties in the decision-making process. Therefore, this paper attempts to overcome the shortcomings of previous approaches and to provide further insight.

In general, the narrow fuzzy parameters in an FFLP application indicate that these parameters have a low range of variation. Thus, the fuzzy parameters of FFLP in this case have slight flexibility. Based on this approach, a new model is proposed in solving FFLP problems, with equality and inequality constraints being handled simultaneously by identifying the maximum and the minimum. Fuzzy solutions can also be determined by this model, specifically when a number or all parameters and variables are triangular and trapezoidal fuzzy numbers.

\section{Preliminary Concepts}

In this section we begin by recalling some basic definitions from fuzzy set theory and introduce the main concepts needed in this paper.

Definition 1. Let $X$ be a collection of objects denoted generically by $x$. The fuzzy set $\widetilde{A}$ in the set of real numbers is called a fuzzy set in $X$ if $\widetilde{A}$ is a set of ordered pairs:

$$
\widetilde{A}=\left\{\left(x, \mu_{\widetilde{A}}(x)\right) \mid x \in X\right\}
$$

where $\mu_{\widetilde{A}}(x)$ is membership function of $x$ in $\mu_{\widetilde{A}}$ such that $\mu_{\widetilde{A}}(x): X \rightarrow[0,1]$.

Definition 2. A fuzzy set $\widetilde{A}$ is called normal if there is a real number $x$ such that $\mu_{\widetilde{A}}(x)=1$.

Definition 3. Let $\widetilde{A}=\left(m^{l}, m^{u}, \alpha, \beta\right)_{L R}$ denote the $L R$-fuzzy number if its membership function is defined as

$$
\mu_{\widetilde{A}}(x)= \begin{cases}L\left(\frac{m^{l}-x}{\alpha}\right), & x<m^{l}, \\ 1, & m^{l} \leq x \leq m^{u}, \\ R\left(\frac{x-m^{u}}{\beta}\right), & x>m^{u}, \\ 0, & \text { otherwise, }\end{cases}
$$

where $L$ and $R$ are reference functions, i.e., $L, R:[0,+\infty) \rightarrow[0,1]$ are non-increasing that $L(0)=R(0)=1$ and $L(1)=R(1)=0$ and $\alpha, \beta \geq 0$. The membership function of a $L R$-type triangular fuzzy number, $\widetilde{A}=(m, \alpha, \beta)_{L R}$, can be also defined as

$$
\mu_{\widetilde{A}}(x)= \begin{cases}L\left(\frac{m-x}{\alpha}\right), & x \leq m . \\ R\left(\frac{x-m}{\beta}\right), & x>m . \\ 0, & \text { otherwise. }\end{cases}
$$

Definition 4. A fuzzy number $\widetilde{A}=\left(m^{l}, m^{u}, \alpha, \beta\right)$ is a trapezoidal fuzzy number if (see Figure $1(\mathrm{a})$ )

$$
\mu_{\widetilde{A}}(x)= \begin{cases}\frac{x-\left(m^{l}-\alpha\right)}{\alpha}, & m^{l}-\alpha \leq x<m^{l} . \\ 1, & m^{l} \leq x \leq m^{u} \\ \frac{\left(m^{u}+\beta\right)-x}{\beta}, & m^{u}<x \leq m^{u}+\beta . \\ 0, & \text { otherwise. }\end{cases}
$$


Definition 5. A fuzzy number $\widetilde{A}=(m, \alpha, \beta)$ is a triangular fuzzy number if (see Figure $1(\mathrm{~b}))$

$$
\mu_{\widetilde{A}}(x)= \begin{cases}\frac{x-(m-\alpha)}{\alpha}, & m-\alpha \leq x<m . \\ \frac{(m+\beta)-x}{\beta}, & m<x \leq m+\beta . \\ 0, & \text { otherwise. }\end{cases}
$$

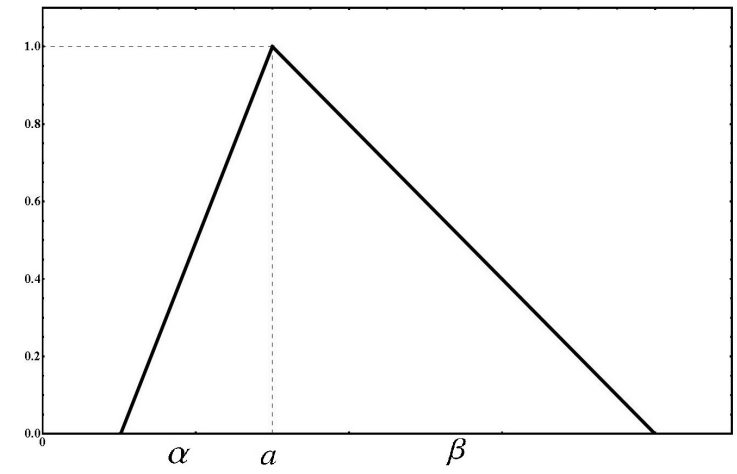

(a) Triangular fuzzy number

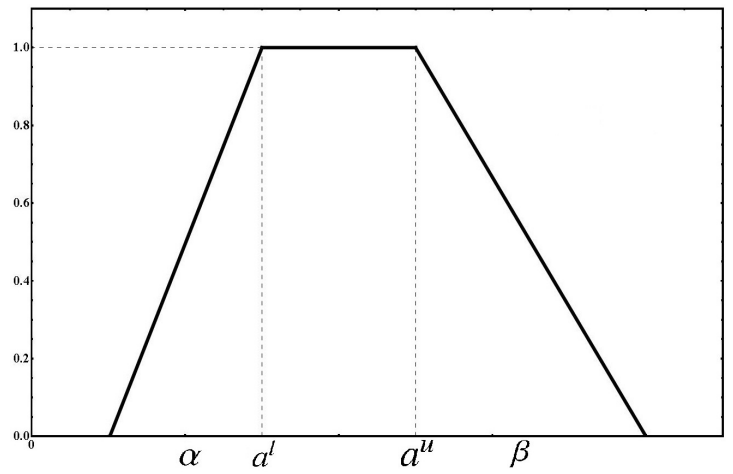

(b) Trapezoidal fuzzy number

Figure 1 . The $L R$-fuzzy numbers.

Definition 6 . Let $\widetilde{A}=\left(m^{l}, m^{u}, \alpha, \beta\right)$ be trapezoidal fuzzy number, then

$$
\begin{array}{lll}
\widetilde{A} \succ 0 & \text { if } \quad m^{l}-\alpha>0 \\
\widetilde{A} \prec 0 & \text { if } \quad m^{u}+\beta<0 .
\end{array}
$$

Definition 7. Let $\widetilde{A}_{1}=\left(m_{1}^{l}, m_{1}^{u}, \alpha_{1}, \beta_{1}\right)$ and $\widetilde{A}_{2}=\left(m_{2}^{l}, m_{2}^{u}, \alpha_{2}, \beta_{2}\right)$ be trapezoidal fuzzy numbers, then we define arithmetic on fuzzy numbers:

$$
\begin{aligned}
& \widetilde{A}_{1}+\widetilde{A}_{2}=\left(m_{1}^{l}+m_{2}^{l}, m_{1}^{u}+m_{2}^{u}, \alpha_{1}+\alpha_{2}, \beta_{1}+\beta_{2}\right) \\
& \widetilde{A}_{1}-\widetilde{A}_{2}=\left(m_{1}^{l}-m_{2}^{u}, m_{1}^{u}-m_{2}^{l}, \alpha_{1}+\beta_{2}, \beta_{1}+\alpha_{2}\right) \\
& \widetilde{A}_{1} \cdot \widetilde{A}_{2}=\left\{\begin{array}{lll}
\left(m_{1}^{l} m_{2}^{l}, m_{1}^{u} m_{2}^{u}, m_{1}^{l} \alpha_{2}+m_{2}^{l} \alpha_{1}, m_{1}^{u} \beta_{2}+m_{2}^{u} \beta_{1}\right), & \widetilde{A}_{1} \succ 0, & \widetilde{A}_{2} \succ 0 . \\
\left(m_{1}^{u} m_{2}^{l}, m_{1}^{l} m_{2}^{u}, m_{1}^{u} \alpha_{2}+m_{2}^{l} \beta_{1}, m_{1}^{l} \beta_{2}+m_{2}^{u} \alpha_{1}\right), & \widetilde{A}_{1} \succ 0, & \widetilde{A}_{2} \prec 0 . \\
\left(m_{1}^{u} m_{2}^{u}, m_{1}^{l} m_{2}^{l},-m_{1}^{u} \beta_{2}-m_{2}^{u} \beta_{1},-m_{1}^{l} \alpha_{2}-m_{2}^{l} \alpha_{1}\right), & \widetilde{A}_{1} \prec 0, & \widetilde{A}_{2} \prec 0 .
\end{array}\right.
\end{aligned}
$$

Remark 1 . We denote the set of all $L R$-fuzzy numbers by $\mathcal{F}(\mathbb{R})$.

Definition 8. [20] A linear ranking function is a function $\mathfrak{R}: \mathcal{F}(\mathbb{R}) \rightarrow \mathbb{R}$, which maps each fuzzy number into a real line, where there is a natural order

$$
\mathfrak{R}(\widetilde{A})=\frac{1}{2} \int_{0}^{1}\left(L_{\alpha}(x)+R_{\alpha}(x)\right) d x
$$

such that

$$
\mathfrak{R}(k \widetilde{A}+\widetilde{B})=k \mathfrak{R}(\widetilde{A})+\mathfrak{R}(\widetilde{B}) .
$$

Let $\widetilde{A}=\left(m^{l}, m^{u}, \alpha, \beta\right)$ be a trapezoidal fuzzy number, then

$$
\mathfrak{R}(\widetilde{A})=\frac{1}{2}\left(m^{l}+m^{u}\right)+\frac{1}{4}(\beta-\alpha) .
$$


If $\widetilde{A}=(a, \alpha, \beta)$ is a triangular fuzzy number, then

$$
\mathfrak{R}(\widetilde{A})=a+\frac{1}{4}(\beta-\alpha) .
$$

Definition 9. [21] Let $\widetilde{m}, \widetilde{n} \in \mathcal{F}(\mathbb{R})$ be fuzzy numbers then

- $\widetilde{A} \succeq \widetilde{B}$ if and only if $\mathfrak{R}(\widetilde{A}) \geq \mathfrak{R}(\widetilde{B})$;

- $\widetilde{A} \preceq \widetilde{B}$ if and only if $\mathfrak{R}(\widetilde{A}) \leq \mathfrak{R}(\widetilde{B})$;

- $\widetilde{A}=\widetilde{B}$ if and only if $\mathfrak{R}(\widetilde{A})=\mathfrak{R}(\widetilde{B})$.

Definition 10. A fully fuzzy linear programming (FFLP) is defined as follows:

$$
\begin{aligned}
\widetilde{Z}^{*}=\operatorname{Min} & \widetilde{c} \widetilde{\mathbf{x}}, \\
\text { s.t. } & \widetilde{A} \widetilde{\mathbf{x}} \succeq \widetilde{b}, \\
& \widetilde{\mathbf{x}} \succeq 0,
\end{aligned}
$$

where $\widetilde{c}=\left(\widetilde{c}_{1}, \ldots, \widetilde{c}_{n}\right), \widetilde{A}=\left(\widetilde{a}_{i j}\right)_{(m \times n)}, \widetilde{b}=\left(\widetilde{b}_{1}, \ldots, \widetilde{b}_{m}\right)^{t}, \widetilde{\mathbf{x}}=\left(\widetilde{x}_{1}, \ldots, \widetilde{x}_{n}\right)^{t}$ and $\widetilde{a}_{i j}, \widetilde{b}_{i}, \widetilde{c}_{j}, \widetilde{x}_{j} \in \mathcal{F}(\mathbb{R})$ for $i=1, \ldots, m, j=1, \ldots, n$.

The decision variables are fuzzy numbers while the coefficients of decision variables and the right hand coefficients are characterized by uncertainties.

Definition 11. The fuzzy vector $\widetilde{\mathbf{x}} \in(\mathcal{F}(\mathbb{R}))^{n}$ is a fuzzy feasible solution to (1) if

$$
\widetilde{A} \widetilde{\mathbf{x}} \succeq \widetilde{b} \quad \text { and } \quad \widetilde{\mathbf{x}} \succeq 0 ;
$$

as a result $\widetilde{\mathbf{x}}$ is a fuzzy feasible solution to (1) if

$$
\mathfrak{R}(\widetilde{A} \widetilde{\mathbf{x}}) \geq \mathfrak{R}(\widetilde{b}) \quad \text { and } \quad \mathfrak{R}(\widetilde{\mathbf{x}}) \geq 0 .
$$

Hence, $S$ be a set of fuzzy numbers which satisfies the set of constraints are defined as follows:

$$
S=\{\widetilde{\mathbf{x}} \mid \mathfrak{R}(\widetilde{A} \widetilde{\mathbf{x}}) \geq \mathfrak{R}(\widetilde{b}) \text { and } \mathfrak{R}(\widetilde{\mathbf{x}}) \geq 0\} .
$$

Definition 12. A fuzzy feasible solution $\widetilde{\mathbf{x}}^{*} \in S$ is a fuzzy optimal solution for (1) if for all fuzzy feasible solution $\widetilde{\mathbf{x}} \in S$ we have

$$
\widetilde{c} \widetilde{\mathbf{x}}^{*} \preceq \widetilde{c} \widetilde{\mathbf{x}}
$$

as a result $\widetilde{\mathbf{x}}^{*}$ is a optimal fuzzy optimal feasible solution to (1) if

$$
\mathfrak{R}\left(\widetilde{c} \widetilde{\mathbf{x}}^{*}\right) \leq \mathfrak{R}(\widetilde{c} \widetilde{\mathbf{x}}) .
$$

\section{Solving Fully Fuzzy Linear Programming}

In this section a new method in finding the fuzzy optimal solution of the FFLP model (1) is proposed. This method can be used to solve FFLP problems with equality and inequality constraints by identifying the maximum and the minimum. This method can also be used in solving FFLP problems with triangular and trapezoidal fuzzy parameters. Furthermore, by controlling the left and the right side values of fuzzy parameters to make them proportional with other fuzzy parameters, the generation of broad fuzzy variables is prevented.

For this purpose we obtained an upper bound for the left $\left(\alpha_{x_{j}}\right)$ and the right $\left(\beta_{x_{j}}\right)$ sides of the fuzzy values. The upper bound is prevented from exceeding $\alpha_{x_{j}}$ and $\beta_{x_{j}}$. Consequently, the obtained fuzzy solutions are not considerably broad but are controlled and thinner fuzzy solutions. In this paper, the upper bounds for $\alpha_{x_{j}}$ and $\beta_{x_{j}}$ are proportional to the ratio of the left and the right side values to the central value of fuzzy parameters. Thus, we calculated the values of $\alpha_{x_{j}}, \beta_{x_{j}}$ and $m_{x_{j}}$, such that the maximum value of the ratio of $\alpha_{x_{j}}$ and $\beta_{x_{j}}$ to $m_{x_{j}}$ is equal to $M$. By adding the following constraints to the problem fuzzy variables can be prevented from becoming exceedingly broad:

$$
\frac{\alpha_{x_{j}}}{\left|m_{x_{j}}\right|} \leq M, \quad \quad \frac{\beta_{x_{j}}}{\left|m_{x_{j}}\right|} \leq M, \quad j=1,2, \cdots, n .
$$


Two solutions for the calculation of $M$ are proposed. Firstly, $M$ is calculated by acquiring the maximum amount of the ratio of $\alpha$ and $\beta$ to $m$ for all fuzzy parameters of FFLP. Secondly, $M$ is calculated by their mean.

The fully fuzzy linear programming (1) can be rewritten as follows:

$$
\begin{array}{ll}
\operatorname{Min} & \sum_{j=1}^{n} \widetilde{c}_{j} \widetilde{x}_{j}, \\
\text { s.t. } & \sum_{j=1}^{n} \widetilde{a}_{i j} \widetilde{x}_{j} \succeq \widetilde{b}_{i} \quad, \quad i=1,2, \cdots, m, \\
& \widetilde{x}_{j} \succeq 0 \quad, \quad j=1,2, \cdots, n,
\end{array}
$$

where $\widetilde{c}_{j}=\left(m_{c_{j}}, \alpha_{c_{j}}, \beta_{c_{j}}\right), \widetilde{a}_{i j}=\left(m_{a_{i j}}, \alpha_{a_{i j}}, \beta_{a_{i j}}\right), \widetilde{b}_{i}=\left(m_{b_{i}}, \alpha_{b_{i}}, \beta_{b_{i}}\right), \widetilde{x}_{j}=\left(m_{x_{j}}, \alpha_{x_{j}}, \beta_{x_{j}}\right)$ are triangular fuzzy numbers and $\widetilde{a}_{i j}, \widetilde{b}_{i}, \widetilde{c}_{j}, \widetilde{x}_{j} \in \mathcal{F}(\mathbb{R})$ for $i=1,2, \ldots, m, j=1,2, \ldots, n$.

We use the ranking function that was defined in Definition 8 for the defuzzification of the fully fuzzy linear programming (3) and by adding constraints (2) then we have

$$
\begin{array}{lll}
\text { Min } & \Re\left(\sum_{j=1}^{n} \widetilde{c}_{j} \widetilde{x}_{j}\right) & \\
\text { s.t. } & \mathfrak{R}\left(\sum_{j=1}^{n} \widetilde{a}_{i j} \widetilde{x}_{j}\right) \geq \mathfrak{R}\left(\widetilde{b}_{i}\right) \quad, \quad i=1,2, \cdots, m, \\
& \frac{\alpha_{x_{j}}}{\left|m_{x_{j}}\right|} \leq M & , j=1,2, \cdots, n, \\
& \frac{\beta_{x_{j}}}{\left|m_{x_{j}}\right|} \leq M & , j=1,2, \cdots, n, \\
& \mathfrak{R}\left(\widetilde{x}_{j}\right) \geq 0 & , j=1,2, \cdots, n,
\end{array}
$$

where

$$
M=\max _{\substack{i=1,2, \ldots, m \\ j=1,2, \ldots, n}}\left\{\frac{\alpha_{a_{i j}}}{\left|m_{a_{i j}}\right|}, \frac{\beta_{a_{i j}}}{\left|m_{a_{i j}}\right|}, \frac{\alpha_{b_{i}}}{\left|m_{b_{i}}\right|}, \frac{\beta_{b_{i}}}{\left|m_{b_{i}}\right|}, \frac{\alpha_{c_{j}}}{\left|m_{c_{j}}\right|}, \frac{\beta_{c_{j}}}{\left|m_{c_{j}}\right|} \mid m_{a_{i j}} \neq 0, m_{b_{i}} \neq 0, m_{c_{j}} \neq 0\right\}
$$

or

$$
M=\operatorname{mean}_{\substack{i=1,2, \ldots, m \\ j=1,2, \ldots, n}}\left\{\frac{\alpha_{a_{i j}}}{\left|m_{a_{i j}}\right|}, \frac{\beta_{a_{i j}}}{\left|m_{a_{i j}}\right|}, \frac{\alpha_{b_{i}}}{\left|m_{b_{i}}\right|}, \frac{\beta_{b_{i}}}{\left|m_{b_{i}}\right|}, \frac{\alpha_{c_{j}}}{\left|m_{c_{j}}\right|}, \frac{\beta_{c_{j}}}{\left|m_{c_{j}}\right|} \mid m_{a_{i j}} \neq 0, m_{b_{i}} \neq 0, m_{c_{j}} \neq 0\right\} .
$$

According to $\widetilde{x}_{j} \succeq 0$ we have

$$
\frac{\alpha_{x_{j}}}{m_{x_{j}}} \leq M \quad \text { and } \quad \frac{\beta_{x_{j}}}{m_{x_{j}}} \leq M, \quad j=1,2, \cdots, n
$$

Then

$$
M m_{x_{j}}-\alpha_{x_{j}} \geq 0 \quad \text { and } \quad M m_{x_{j}}-\beta_{x_{j}} \geq 0, \quad j=1,2, \cdots, n .
$$

Thus, we can write model (4) as follows:

$$
\begin{array}{rlr}
\text { Min } & \sum_{j=1}^{n} \mathfrak{R}\left(\widetilde{c}_{j} \widetilde{x}_{j}\right) & \\
\text { s.t. } & \sum_{j=1}^{n} \mathfrak{R}\left(\widetilde{a}_{i j} \widetilde{x}_{j} \geq \mathfrak{R}\left(\widetilde{b}_{i}\right) \quad, \quad i=1,2, \cdots, m,\right. \\
& M m_{x_{j}}-\alpha_{x_{j}} \geq 0 \quad, j=1,2, \cdots, n, \\
& M m_{x_{j}}-\beta_{x_{j}} \geq 0 \quad, \quad j=1,2, \cdots, n, \\
& m_{x_{j}}-\alpha_{x_{j}}, \alpha_{x_{j}}, \beta_{x_{j}} \geq 0 \quad, \quad j=1,2, \cdots, n .
\end{array}
$$


A standard form on a fully fuzzy linear programming (FFLP) is also defined as follows:

$$
\begin{aligned}
\widetilde{Z}^{*}=\operatorname{Min} & \widetilde{c} \widetilde{\mathbf{x}} \\
\text { s.t. } & \widetilde{A} \widetilde{\mathbf{x}}=\widetilde{b} ; \\
& \widetilde{\mathbf{x}} \succeq 0 ;
\end{aligned}
$$

then we have

$$
\begin{array}{lll}
\text { Min } & \sum_{j=1}^{n} \mathfrak{R}\left(\widetilde{c}_{j} \widetilde{x}_{j}\right) \\
\text { s.t. } & \sum_{j=1}^{n} \mathfrak{R}\left(\widetilde{a}_{i j} \widetilde{x}_{j}=\mathfrak{R}\left(\widetilde{b}_{i}\right) \quad, \quad i=1,2, \cdots, m,\right. \\
& M m_{x_{j}}-\alpha_{x_{j}} \geq 0 & , j=1,2, \cdots, n, \\
& M m_{x_{j}}-\beta_{x_{j}} \geq 0 \quad, \quad j=1,2, \cdots, n, \\
& m_{x_{j}}-\alpha_{x_{j}}, \alpha_{x_{j}}, \beta_{x_{j}} \geq 0 \quad, \quad j=1,2, \cdots, n .
\end{array}
$$

\section{Numerical Examples}

In this section, two numerical examples are presented to describe the proposed method. The first application is the standard diet problem formulated by Buckley and Feuring [8]. The first example presents FFLP with triangular fuzzy numbers and inequality constraints, while in the second example FFLP with triangular fuzzy numbers is also considered, but with equality constraints. We compared the proposed fuzzy objective optimal solution with that from other models by Fortemps and Roubens [22], Chang [23] and Liou and Wang [24] that use ranking function.

Example 1. Let us start by considering the following fully fuzzy linear program problem.

A farmer has three products P1, P2 and P3 to mix together to feed his pigs. He knows that the pigs need a certain amount of foods $F 1$ and $F 2$ per day. Table 1 illustrates the units of $F 1$ and $F 2$ that are available per gram of $P 1, P 2$ and $P 3$. Also, each pig should have at least $(54,4,4)$ units of $F 1$ and at least $(60,4,4)$ units of $F 2$ per day. The costs of $P 1, P 2$ and $P 3$ vary slightly from day to day but the average costs are $(8,1,1) \phi$ per gram of $P 1, P 2$ is $(9,1,1) \notin$ per gram, and $(10,1,1) \notin$ gram for $P 3$. The farmer therefore wants to know how many grams of $P 1, P 2$ and $P 3$ he should mix together each day, so that his pigs could get the approximate minimum requirement and his costs reduce.

Approximate units of food $F_{j}$ and product $P_{i}$ Example 1

\begin{tabular}{lccc}
\hline \multicolumn{5}{c}{ Foods } & F2 & Average costs \\
\hline Products & F1 & $(5,0.5,0.5)$ & $(8,1,1)$ \\
\hline P1 & $(2.5,0.5,0.5)$ & $(3,0.5,0.5)$ & $(9,1,1)$ \\
P2 & $(4.5,0.5,0.5)$ & $(10,1.0,1.0)$ & $(10,1,1)$ \\
P3 & $(5,0.5,0.5)$ & $(10)$ \\
\hline
\end{tabular}

Buckley and Feuring $[8]$ have formulated a standard diet problem as follows:

$$
\begin{aligned}
\text { Min } & (8,1,1) \widetilde{x}_{1}+(9,1,1) \widetilde{x}_{2}+(10,1,1) \widetilde{x}_{3} \\
\text { s.t. } & (2.5,0.5,0.5) \widetilde{x}_{1}+(4.5,0.5,0.5) \widetilde{x}_{2}+(5,0.5,0.5) \widetilde{x}_{3} \succeq(54,4,4) \\
& (5 \quad, 0.5,0.5) \widetilde{x}_{1}+(3 \quad, 0.5,0.5) \widetilde{x}_{2}+(10,1 \quad, 1 \quad) \widetilde{x}_{3} \succeq(60,4,4) \\
& \widetilde{x}_{1}, \widetilde{x}_{2}, \widetilde{x}_{3} \succeq 0,
\end{aligned}
$$

where $\widetilde{x}_{j}$ is triangular fuzzy numbers as follows:

$$
\widetilde{x}_{j}=\left(m_{x_{j}}, \alpha_{x_{j}}, \beta_{x_{j}}\right), \quad j=1,2,3 .
$$


In this example, we used formula (6) to calculate $M$ for control the left and the right side of fuzzy variables proportional to other fuzzy parameters.

$$
\begin{aligned}
M= & \operatorname{mean}_{\substack{i=1,2 \\
j=1,2,3}}\left\{\frac{\alpha_{a_{i j}}}{\left|m_{a_{i j} \mid}\right|}, \frac{\beta_{a_{i j}}}{\left|m_{a_{i j}}\right|}, \frac{\alpha_{b_{i}}}{\left|m_{b_{i}}\right|}, \frac{\beta_{b_{i}}}{\left|m_{b_{i}}\right|}, \frac{\alpha_{c_{j}}}{\left|m_{c_{j}}\right|}, \frac{\beta_{c_{j}}}{\left|m_{c_{j}}\right|} \mid m_{a_{i j}} \neq 0, m_{b_{i}} \neq 0, m_{c_{j}} \neq 0\right\} \\
= & \operatorname{mean}\left\{\frac{0.5}{|2.5|}, \frac{0.5}{|2.5|}, \frac{0.5}{|4.5|}, \frac{0.5}{|4.5|}, \frac{0.5}{|5|}, \frac{0.5}{|5|}, \frac{0.5}{|5|}, \frac{0.5}{|5|}, \frac{0.5}{|3|}, \frac{0.5}{|3|}, \frac{1}{|10|}, \frac{1}{|10|},\right. \\
& \left.\frac{4}{|54|}, \frac{4}{|54|}, \frac{4}{|60|}, \frac{4}{|60|}, \frac{1}{|8|}, \frac{1}{|8|}, \frac{1}{|9|}, \frac{1}{|9|}, \frac{1}{|10|}, \frac{1}{|10|}\right\}=0.11 .
\end{aligned}
$$

By using the model (7) we convert the FFLP (9) to following model:

$$
\begin{aligned}
\text { Min } & 8 m_{x_{1}}+9 m_{x_{2}}+10 m_{x_{3}}-2 \alpha_{x_{1}}-2.25 \alpha_{x_{2}}-2.5 \alpha_{x_{3}}+2 \beta_{x_{1}}+2.25 \beta_{x_{2}}+2.5 \beta_{x_{3}} \\
\text { s.t. } & 2.5 m_{x_{1}}+4.5 m_{x_{2}}+5 m_{x_{3}}-0.625 \alpha_{x_{1}}-1.125 \alpha_{x_{2}}-1.25 \alpha_{x_{3}}+0.625 \beta_{x_{1}}+1.125 \beta_{x_{2}}+1.25 \beta_{x_{3}} \geq 54 \\
& 5 m_{x_{1}}+3 m_{x_{2}}+10 m_{x_{3}}-1.25 \alpha_{x_{1}}-0.75 \alpha_{x_{2}}-2.5 \alpha_{x_{3}}+1.25 \beta_{x_{1}}+0.75 \beta_{x_{2}}+2.5 \beta_{x_{3}} \geq 60 \\
& 0.11 m_{x_{j}}-\alpha_{x_{j}} \geq 0, \quad j=1,2,3 \\
& 0.11 m_{x_{j}}-\beta_{x_{j}} \geq 0, \quad j=1,2,3 \\
& m_{x_{j}}-\alpha_{x_{j}} \geq 0, \quad \alpha_{x_{j}} \geq 0, \quad \beta_{x_{j}} \geq 0, \quad j=1,2,3 .
\end{aligned}
$$

As a result, the fuzzy optimal solutions obtained are as follows:

$$
\widetilde{x}_{1}^{*}=(0,0,0), \quad \widetilde{x}_{2}^{*}=(0,0,0), \quad \widetilde{x}_{3}^{*}=(10.5,0,1.2), \quad \widetilde{Z}^{*}=(105,10.5,22.5) .
$$

The following is the fuzzy optimal solution obtained from Buckley and Feuring [8]:

$$
\widetilde{x}_{1}^{B *}=(6.4,6.4,0), \quad \widetilde{x}_{2}^{B *}=(11.5,11.5,0), \quad \widetilde{x}_{3}^{B *}=(2,2,0), \quad \widetilde{Z}^{B *}=(173,173,20) .
$$

The solutions of the method by Buckley were considerably broad, whereas all fuzzy parameters in this example are narrow. In addition, the range of variation in these parameters is low, implying that the solutions obtained by the method by Buckley are not homogeneous with the fuzzy parameters. Comparison between the obtained optimal fuzzy variable solutions by the proposed method and those by the method of Buckley revealed that the optimal fuzzy variable solutions $\left(\widetilde{x}_{j}^{*}\right)$ by the former are narrower than those $\left(\widetilde{x}_{j}^{B *}\right)$ by the latter (Figures 2(d), 2(e) and 2(f)). Specifically, $\widetilde{x}_{1}^{B *}$ and $\widetilde{x}_{2}^{B *}$ were wider than $\widetilde{x}_{1}^{*}$ and $\widetilde{x}_{2}^{*}$. Thus, the fuzzy solutions acquired by the proposed method are homogeneous with the fuzzy parameters of the fuzzy problem. We subsequently compared the fuzzy objective optimal solutions obtained by both methods by performing several methods of comparison of fuzzy numbers, and the results are shown in Table 2. All ranking functions indicated that the fuzzy objective optimal solution by the proposed method is better than that by the method of Buckley, except for the Liou and Wang ranking function with $\lambda=0$ that exhibits the fuzzy objective optimal solution by the method of Buckley as much broader than that by the proposed method. Therefore, a farmer can produce food for his pigs at a reduced price, given that all conditions are satisfied. With regards to decisions related to the narrow fuzzy variable, the farmer must best speculate the amounts of $P 1, P 2$, and $P 3$ products to be mixed together.

Comparison of our optimal solution with optimal solution of Buckley on the FFLP in Example 1

\begin{tabular}{lccc}
\hline Ranking Functions & $\widetilde{Z}^{*}$ & $\widetilde{Z}^{B *}$ & Ranking results \\
\hline Fortemps and Roubens & 108 & 134.8 & $\widetilde{Z}^{*} \preceq \widetilde{Z}^{B *}$ \\
Chang & 1797 & 11773 & $\widetilde{Z}^{*} \preceq \widetilde{Z}^{B *}$ \\
Liou and Wang $\lambda=0$ & 99.7 & 86.5 & $\widetilde{Z}^{*} \succeq \widetilde{Z}^{B *}$ \\
Liou and Wang $\lambda=0.5$ & 108 & 134.8 & $\widetilde{Z}^{*} \preceq \widetilde{Z}^{B *}$ \\
Liou and Wang $\lambda=1$ & 116.2 & 183 & $\widetilde{Z}^{*} \preceq \widetilde{Z}^{B *}$ \\
\hline
\end{tabular}




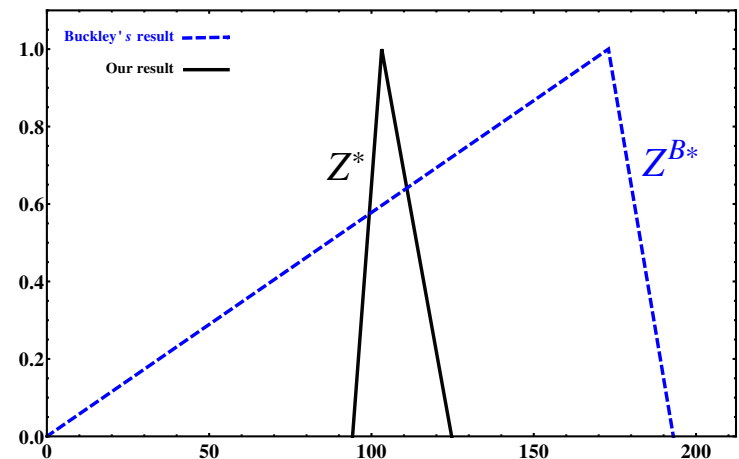

(c) $\widetilde{Z}^{*}$

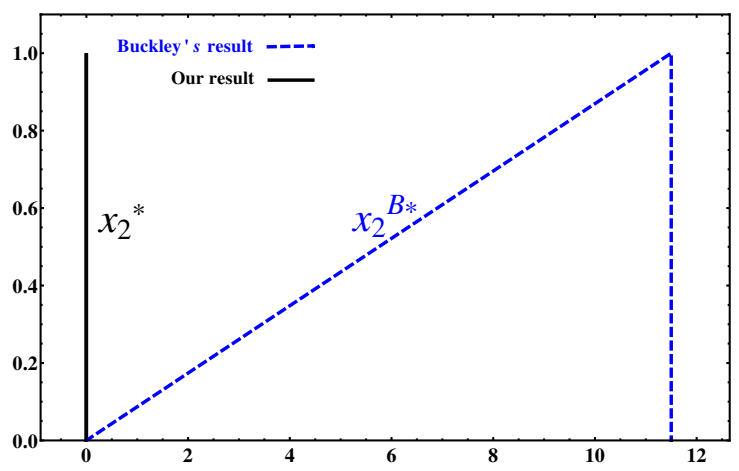

(e) $\widetilde{x}_{2}^{*}$

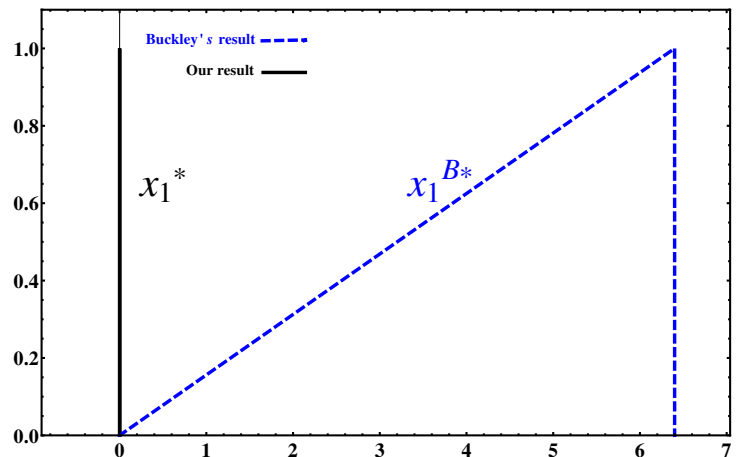

(d) $\widetilde{x}_{1}^{*}$

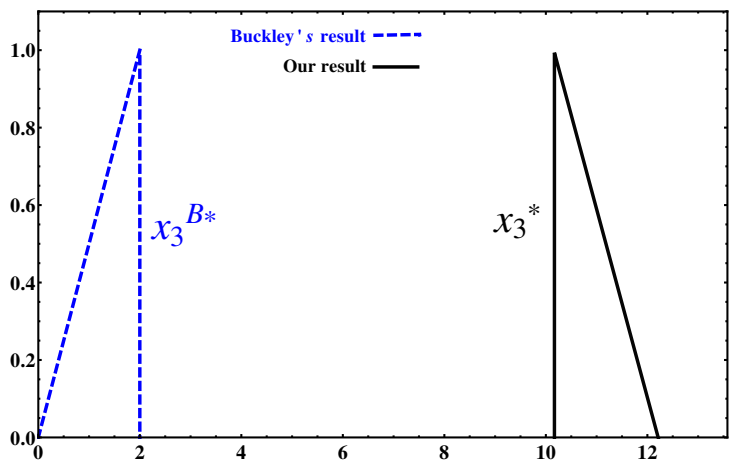

(f) $\widetilde{x}_{3}^{*}$

Figure 2. The graphical comparison of the results obtained from this study with the results represented by Buckley and Feuring [8] in Example 1

Example 2. Consider the following fuzzy linear program [17].

$$
\begin{aligned}
\operatorname{Max} & (15,5,2) \widetilde{x}_{1}+(16,6,4) \widetilde{x}_{2}+(14,4,3) \widetilde{x}_{3}+(12,2,2) \widetilde{x}_{4} \\
\text { s.t. } & (10,2,3) \widetilde{x}_{1}+(11,1,2) \widetilde{x}_{2}+(12,3,1) \widetilde{x}_{3}+(15,4,2) \widetilde{x}_{4}=(411.75,140,162) \\
& (14,2,2) \widetilde{x}_{1}+(18,4,1) \widetilde{x}_{2}+(17,3,3) \widetilde{x}_{3}+(14,1,4) \widetilde{x}_{4}=(539.5,154,220) \\
& \widetilde{x}_{1}, \widetilde{x}_{2}, \widetilde{x}_{3}, \widetilde{x}_{4} \succeq 0,
\end{aligned}
$$

where $\widetilde{x}_{j}$ is triangular fuzzy numbers as follows:

$$
\widetilde{x}_{j}=\left(m_{x_{j}}, \alpha_{x_{j}}, \beta_{x_{j}}\right), \quad j=1,2,3 \text { and } 4 .
$$

In this example, we used Formula (5) in order to calculate $M$ and control the left and the right side of fuzzy variable proportional to other fuzzy parameters.

$$
\begin{aligned}
M= & \max _{\substack{i=1,2 \\
j=1,2,3,4}}\left\{\frac{\alpha_{a_{i j}}}{\left|m_{a_{i j}}\right|}, \frac{\beta_{a_{i j}}}{\left|m_{a_{i j}}\right|}, \frac{\alpha_{b_{i}}}{\left|m_{b_{i}}\right|}, \frac{\beta_{b_{i}}}{\left|m_{b_{i}}\right|}, \frac{\alpha_{c_{j}}}{\left|m_{c_{j}}\right|}, \frac{\beta_{c_{j}}}{\left|m_{c_{j}}\right|} \mid m_{a_{i j}} \neq 0, m_{b_{i}} \neq 0, m_{c_{j}} \neq 0\right\} \\
= & \max \left\{\frac{2}{|10|}, \frac{3}{|10|}, \frac{1}{|11|}, \frac{2}{|11|}, \frac{3}{|12|}, \frac{1}{|12|}, \frac{4}{|15|}, \frac{2}{|15|}, \frac{2}{|14|}, \frac{2}{|14|}, \frac{4}{|18|}, \frac{1}{|18|}, \frac{3}{|17|}, \frac{3}{|17|}, \frac{1}{|14|}, \frac{4}{|14|},\right. \\
& \left.\frac{140}{|411.75|}, \frac{162}{|411.75|}, \frac{154}{|539.5|}, \frac{220}{|539.5|}, \frac{5}{|15|}, \frac{2}{|15|}, \frac{6}{|16|}, \frac{4}{|16|}, \frac{4}{|14|}, \frac{3}{|14|}, \frac{2}{|12|}, \frac{2}{|12|}\right\}=0.408 .
\end{aligned}
$$

By using Model (8) for maximization form of fully fuzzy linear programming, we convert the FFLP (10) to the following model: 


$$
\begin{array}{ll}
\text { Max } & 15 m_{x_{1}}+16 m_{x_{2}}+14 m_{x_{3}}+12 m_{x_{4}}+\frac{1}{4}\left(-3 m_{x_{1}}-2 m_{x_{2}}-m_{x_{3}}\right. \\
& \left.-15 \alpha_{x_{1}}-16 \alpha_{x_{2}}-14 \alpha_{x_{3}}-12 \alpha_{x_{4}}+15 \beta_{x_{1}}+16 \beta_{x_{2}}+14 \beta_{x_{3}}+12 \beta_{x_{4}}\right) \\
\text { s.t. } \quad & 10 m_{x_{1}}+11 m_{x_{2}}+12 m_{x_{3}}+15 m_{x_{4}}+\frac{1}{4}\left(m_{x_{1}}+m_{x_{2}}-2 m_{x_{3}}-2 m_{x_{4}}\right. \\
& \left.-10 \alpha_{x_{1}}-11 \alpha_{x_{2}}-12 \alpha_{x_{3}}-15 \alpha_{x_{4}}+10 \beta_{x_{1}}+11 \beta_{x_{2}}+12 \beta_{x_{3}}+15 \beta_{x_{4}}\right)=417.25 \\
& 14 m_{x_{1}}+18 m_{x_{2}}+17 m_{x_{3}}+14 m_{x_{4}}+\frac{1}{4}\left(-3 m_{x_{2}}+3 m_{x_{4}}\right. \\
& \left.-14 \alpha_{x_{1}}-18 \alpha_{x_{2}}-17 \alpha_{x_{3}}-14 \alpha_{x_{4}}+14 \beta_{x_{1}}+18 \beta_{x_{2}}+17 \beta_{x_{3}}+14 \beta_{x_{4}}\right)=556 \\
& 0.408 m_{x_{j}}-\alpha_{x_{j}} \geq 0, \quad j=1,2,3,4 \\
& 0.408 m_{x_{j}}-\beta_{x_{j}} \geq 0, \quad j=1,2,3,4 \\
& m_{x_{j}}-\alpha_{x_{j}} \geq 0, \quad \alpha_{x_{j}} \geq 0, \quad \beta_{x_{j}} \geq 0, \quad j=1,2,3,4 .
\end{array}
$$

As a result, the fuzzy optimal solutions are as follows:

$$
\begin{gathered}
\widetilde{x}_{1}^{*}=(33.23,0,13.57), \quad \widetilde{x}_{2}^{*}=(0,0,0), \quad \widetilde{x}_{3}^{*}=(0,0,0), \quad \widetilde{x}_{4}^{*}=(2.63,0,1.07) \\
\widetilde{Z}^{*}=(531,172,228)
\end{gathered}
$$

This example has been solved by Lotfi et al. [17]. They have solved this example by solving two linear programming problem. The fuzzy solutions of first and second linear programming problem are $\widetilde{x}_{j}^{H 1 *}$ and $\widetilde{x}_{j}^{H 2 *}(j=1,2,3,4)$, respectively (Figure 3$)$. Then, fuzzy objective solution has been obtained by using the fuzzy solutions of these linear programming problem. The following results have been obtained:

$$
\begin{gathered}
\widetilde{x}_{1}^{H 1 *}=(38.14,10.25,0), \quad \widetilde{x}_{2}^{H 1 *}=(0,0,3.31), \quad \widetilde{x}_{3}^{H 1 *}=(0,0,0), \quad \widetilde{x}_{4}^{H 1 *}=(2.65,0,0) \\
\widetilde{x}_{1}^{H 2 *}=(37.47,8.33,0), \quad \widetilde{x}_{2}^{H 2 *}=(0,0,3.82), \quad \widetilde{x}_{3}^{H 2 *}=(0,0,0), \quad \widetilde{x}_{4}^{H 2 *}=(2.97,1.18,0) \\
\widetilde{Z}^{H *}=(560,226.3,226.3)
\end{gathered}
$$

In this example, we show that the proposed method can also solve FFLP problems with equality constraints by focusing on one linear programming problem only. Comparison of the optimal fuzzy variable solutions of the proposed method and those of the method by Lofti et al. revealed that $\widetilde{x}_{2}^{H 1 *}$ and $\widetilde{x}_{2}^{H 2 *}$ are wider than $\widetilde{x}_{2}^{*}$. (Figure 3(i)) Moreover, $\widetilde{x}_{3}^{H 1 *}=\widetilde{x}_{3}^{H 2 *}=\widetilde{x}_{3}^{*}$ and the widths of $\widetilde{x}_{1}^{H 1 *}$ (or $\widetilde{x}_{1}^{H 2 *}$ ) and $\widetilde{x}_{4}^{H 2 *}$ are almost identical to that of $\widetilde{x}_{1}^{*}$ and $\widetilde{x}_{4}^{*}$, respectively (Figures $3(\mathrm{~h})$ and $3(\mathrm{j})$ ). Furthermore, Lotfi et al. obtained two fuzzy solutions corresponding to each fuzzy variable. However, the fuzzy solutions were difficult to determine. Table 3 displays the comparison between the obtained fuzzy objective optimal solutions of the proposed method and those of Lotfi et al. who employed various methods in comparing fuzzy numbers. The obtained solutions by the proposed methods are narrower and more controlled than those of Lotfi et al. All ranking functions indicated that the obtained fuzzy objective optimal solution of the proposed method is better than that of Lotfi et al.

\section{Comparison of our optimal solution with optimal solution} of F. H. Lotfi [17] on the FFLP in Example 2

\begin{tabular}{lccc}
\hline Ranking Functions & $\widetilde{Z}^{*}$ & $\widetilde{Z}^{H *}$ & Ranking results \\
\hline Fortemps and Roubens & 560 & 560 & $\widetilde{Z}^{*} \succeq \widetilde{Z}^{H *}$ \\
Chang & 130997 & 126728 & $\widetilde{Z}^{*} \succeq \widetilde{Z}^{H *}$ \\
Liou and Wang $\lambda=0$ & 444.95 & 444.85 & $\widetilde{Z}^{*} \succeq \widetilde{Z}^{H *}$ \\
Liou and Wang $\lambda=0.5$ & 560 & 560 & $\widetilde{Z}^{*} \succeq \widetilde{Z}^{H *}$ \\
Liou and Wang $\lambda=1$ & 674.9 & 673.1 & $\widetilde{Z}^{*} \succeq \widetilde{Z}^{H *}$ \\
\hline
\end{tabular}




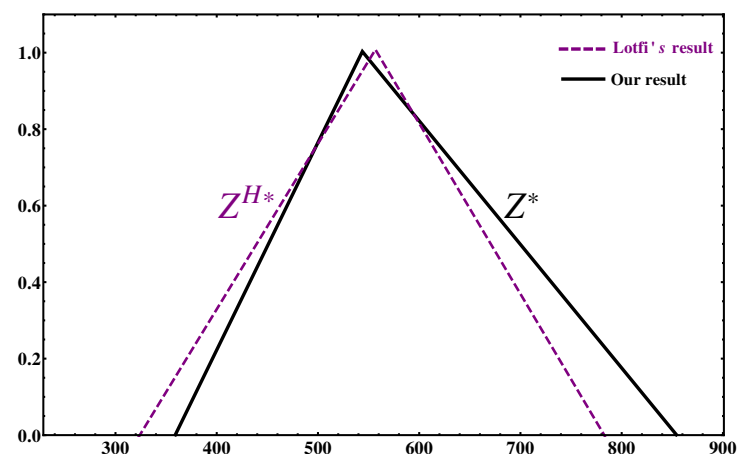

(g) $\widetilde{Z}^{*}$

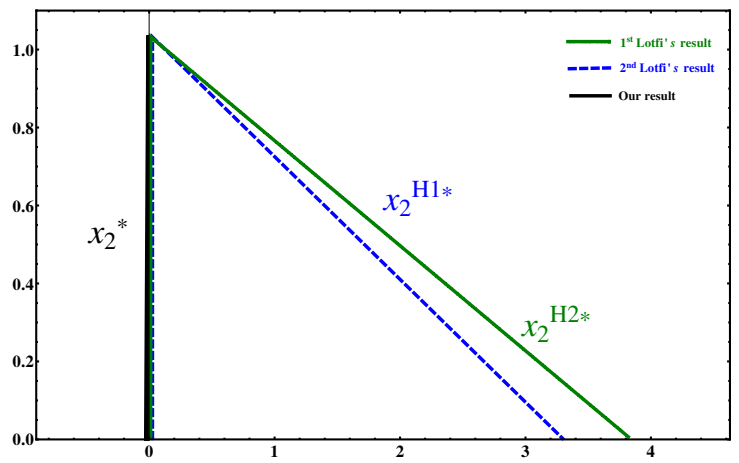

(i) $\widetilde{x}_{2}^{*}$

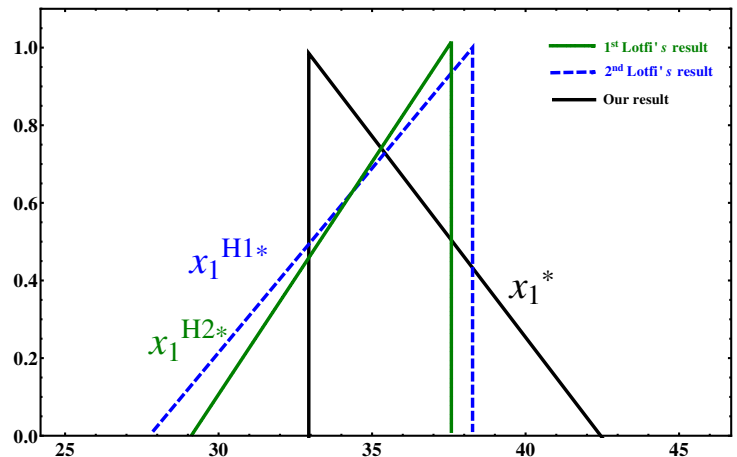

(h) $\widetilde{x}_{1}^{*}$

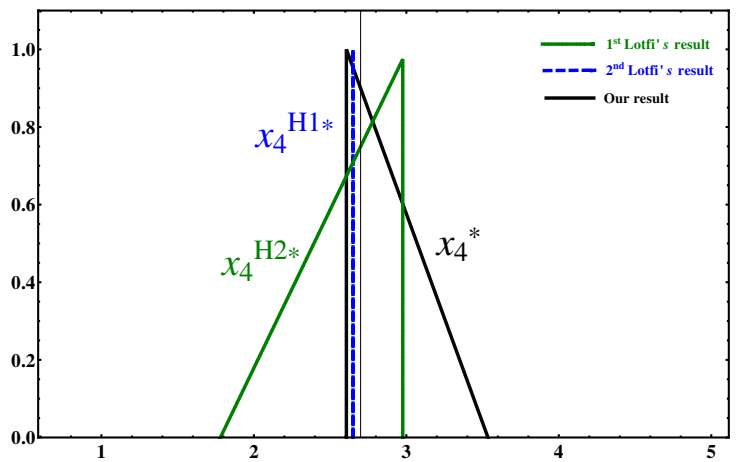

(j) $\widetilde{x}_{4}^{*}$

Figure 3. The graphical comparison of the results obtained from this study with the results represented by Lotfi et al. [17] in Example 2

\section{Conclusion}

In this paper a new method of solving fuzzy linear programming problems is proposed. The suggested method can solve fuzzy linear programming models with equality and inequality constraints by maximization and minimization, and by solving one linear programming problem only. By considering the constraints $M m_{x_{j}}-\alpha_{x_{j}} \geq 0$ and $M m_{x_{j}}-\beta_{x_{j}} \geq 0$, the proposed model was able to control the left and the right sides of fuzzy variables with respect to other fuzzy parameters of the problem. Therefore, the homogeneity among fuzzy solutions and other fuzzy parameters of the problem can be achieved. In addition, this model prevents the generation of broad fuzzy solutions, therefore, making the appropriate decision-making process easier and more convenient. Moreover, the fuzzy objective optimal solutions obtained by the proposed method are better than those by other methods, whereas the fuzzy solutions obtained by the proposed method are also more limited and narrower.

\section{References}

1 Zadeh, L.A. (1965). Fuzzy sets. Information and Control, 8, 338-353.

2 Bellman, R.E., \& Zadeh, L.A. (1970). Decision-making in a fuzzy environment. Management Science, $17,141-164$.

3 Tanaka, H., Okuda, T., \& Asai, K. (1973). On fuzzy-mathematical programming. Journal of Cybernetics, 3, 37-46.

4 Zimmermann, H.-J. (1978). Fuzzy programming and linear programming with several objective functions, Fuzzy Sets and Systems, 1, 45-55.

5 Chanas, S. (1983). The use of parametric programming in fuzzy linear programming, Fuzzy Sets and Systems, 11, 229-241.

6 Werners, B. (1987). An interactive fuzzy programming system. Fuzzy Sets and Systems, 23, 131-147. 
7 Fang, S.-C., Hu, C.-F., Wang, H.-F., \& Wu, S.-Y. (1999). Linear programming with fuzzy coefficients in constraints. Computers \& Mathematics with Applications, 37, 63-76.

8 Buckley, J.J., \& Feuring, T. (2000). Evolutionary algorithm solution to fuzzy problems: Fuzzy linear programming. Fuzzy Sets and Systems, 109, 35-53.

9 Maleki, H., Tata, M., \& Mashinchi, M. (2000). Linear programming with fuzzy variables. Fuzzy Sets and Systems, 109, 21-33.

10 Maleki, H. (2002). Ranking functions and their applications to fuzzy linear programming. Far East Journal of Mathematical Sciences, 4, 283-301.

11 Nehi, H. M., Maleki, H. R., \& Mashinchi, M. (2004). Solving fuzzy number linear programming problem by lexicographic ranking function. Italian Journal of Pure and Applied Mathematics, 15, 9-20.

12 Ganesan, K., \& Veeramani, P. (2006). Fuzzy linear programs with trapezoidal fuzzy numbers. Annals of Operations Research, 143, 305-315.

13 Hashemi, S.M., Modarres, M., Nasrabadi, E., \& Nasrabadi, M. M. (2006). Fully fuzzified linear programming, solution and duality. J. Intell. Fuzzy Syst., 17, 253-261.

14 Rommelfanger, H. (2007). A general concept for solving linear multicriteria programming problems with crisp, fuzzy or stochastic values. Fuzzy Sets and Systems, 158, 1892-1904.

15 Allahviranloo, T., H. Lotfi, F., Kiasary, M.K., Kiani, N.A., \& Alizadeh, L. (2008). Solving fully fuzzy linear programming problem by the ranking functhion. Applied Matematical Sciences, 2, 19-32.

16 Nasseri, S.H. (2008). A new method for solving fuzzy linear programming by solving linear programming. Applied Matematical Sciences, 2, 2473-2480.

17 Lotfi, F.H., Allahviranloo, T., Jondabeh, M.A., \& Alizadeh, L. (2009). Solving a full fuzzy linear programming using lexicography method and fuzzy approximate solution. Applied Mathematical Modelli$n g$, 33, 3151-3156.

18 Ebrahimnejad, A. \& Nasseri, S.H. (2009). Using complementary slackness property to solve linear programming with fuzzy parameters. Fuzzy Information and Engineering, 1, 233-245.

19 Kumar, A., Kaur, J., \& Singh, P. (2010). Fuzzy optimal solution of fully fuzzy linear programming problems with inequality constraints. International Journal of Mathematical and Computer Sciences, 6, $37-41$.

20 Yager, R.R. (1981). A procedure for ordering fuzzy subsets of the unit interval. Information Sciences, 24, $143-161$.

21 Asady, B., \& Zendehnam, A. (2007). Ranking fuzzy numbers by distance minimization. Applied Mathematical Modelling, 31, 2589-2598.

22 Fortemps, P., \& Roubens, M. (1996). Ranking and defuzzification methods based on area compensation. Fuzzy Sets and Systems, 82, 319-330.

23 Cheng, C.-H. (1998). A new approach for ranking fuzzy numbers by distance method. Fuzzy Sets and Systems, 95, 307-317.

24 Liou, T.-S., \& Wang, M.-J. J. (1992). Ranking fuzzy numbers with integral value. Fuzzy Sets and Systems, $50,247-255$.

С.М. Давуди, Н.А. Абдул Рахман

Математика вылымдары мектебі, Малайзия вылыми университеті, Пенанг, Малайзия

\section{Айнымалылардың өзгеру диапазонын басқару арқылы сызықтық бағдарламалаудың толық анық емес мәселелерін шешу}

\footnotetext{
Мақалада шешім айнымалыларының коэффициенттері, оң коэффициенттер және айнымалылары анық емес сандармен сипатталатын толық анық емес сызықтық бағдарламалау (FFLP) мәселесі қарастырылған. Анық емес параметрлерге сәйкес анық емес айнымалылардың сол және оң бөліктерін басқару арқылы оңтайлы анық емес шешімдерді алу әдісі ұсынылған. Анық емес басқарылатын шешімдерді қолданса, авторлар күтпеген жауаптардан аулақ болады. Соңында,
} 
ұсынылған модель бірнеше саралау функцияларын қолданатын басқа әдістерге қарағанда жақсы оңтайлы шешім бере алатындығын көрсететін екі сандық мысал келтірілді.

Kiлm сөздер: толық анық емес сызықтық бағдарламалау, анық емес сызықтық бағдарламалау, анық емес сан, саралау функциясы.

\author{
C.M. Давуди, Н.А. Абдул Рахман
}

Школа математических наук; Научный университет Малайзии, Пенанг, Малайзия

\title{
Решение полностью нечетких задач линейного программирования путем управления диапазоном изменения переменных
}

В статье рассмотрена задача полностью нечеткого линейного программирования (FFLP), в которой коэффициенты переменных решения, правые коэффициенты и переменные характеризуются нечеткими числами. Предложен метод получения оптимальных нечетких решений путем управления левой и правой частями нечетких переменных в соответствии с нечеткими параметрами. Используя нечеткие контролируемые решения, авторы избежали неожиданных ответов. Таким образом, приведены решения двух численных примеров, демонстрирующих как предлагаемая модель может обеспечить лучшее оптимальное решение, чем другие методы, использующие несколько функций ранжирования.

Ключевые слова: полностью нечеткое линейное программирование, нечеткое линейное программирование, нечеткое число, функция ранжирования. 